DOI: $10.17805 /$ zpu.2018.1.10

\title{
Социальное государство: исторический генезис и современные модели
}

\author{
Г. Ю. КАНАРШ \\ ИНСТИТУТ ФИЛОСОФИИ РАН
}

В статье поднята ключевая для современного российского общества тема социального государства. Автор обращается к данным социологических исследований, которые свидетельствуют о том, что российское общество не вполне отвечает критериям общества благополучного. С одной стороны, благосостояние российского общества неуклонно увеличивалось на всем протяжении 2000-х и 2010-х годов, однако, с другой стороны, одновременно с этим росли социальные неравенства. В результате российское общество, несмотря на выросший за последние 17 лет уровень зажиточности, характеризуется чрезвычайно высоким уровнем социального расслоения. Это обстоятельство, а также весьма невысокий уровень социальной защищенности российских граждан, по мнению автора статьи, заставляют обратиться к проблеме социального государства.

Автор предлагает использовать сравнительно-исторический подход к анализу формирования социального государства. С его точки зрения, понимание того, какими путями может сформироваться социальное государство в России, предполагает анализ путей его формирования на Западе (Западная Европа и США). В статье анализируются истоки социального государства (проблема пауперизма), исторические способы решения социального вопроса (различные модели социального страхования), а также исследуются основные модели социальной политики (консервативная, либеральная и социал-демократическая).

Основной тезис заключается в том, что социальное государство есть институт, который воплощает в себе практику классового компромисса, готовность господствующих групп поступиться частью своих интересов ради сохранения социальной стабильности. Делается вывод о том, что России ближе социал-демократическая модель социальной политики, однако не все условия для ее реализации имеются в наличии.

Ключевые слова: социальное государство; социальная политика; пауперизм; социальное страхование; консерватизм; либерализм; социал-демократия; Бисмарк; Беверидж; шведская модель 


\section{ВВЕАЕНИЕ}

W уже писали, ссылаясь на работы разных исследователей (социологов, политологов), о том, что в настоящее время идея социальной справедливости приобрела статус подлинной национальной идеи для России (Канарш, 2014), по поводу которой в обществе существует широкий национальный консенсус. Как показывают существующие исследования, ответ на вопрос о социальном благополучии современного российского общества не является однозначным. С одной стороны, на всем протяжении 2000-х и 2010-х годов общее благополучие российского общества постоянно повышалось, что находило выражение в росте потребления (см.: Тихонова, 2016: 39-40). Однако, с другой стороны, рост общего благополучия сопровождался растущей социальной дифференциацией, когда доходы наиболее благополучной в материальном отношении части населения (условно верхние $10 \%$ ) в разы отличались от доходов наименее материально благополучной нижней прослойки (условно нижние $10 \%$ ). Так, различие в доходах верхних и нижних $10 \%$ населения оценивается социологами как девятикратное, а различие между самым верхним и самым нижним процентами уже как сорокакратное (там же: 26). Фиксируется также крайне неравномерное распределение доходов среди населения: так, на долю 60\% населения страны приходится лишь 29,9\% общего объема денежных доходов (там же: 28).

Подавляющее большинство россиян считают существующие неравенства не только чрезмерно большими, но и нелегитимными. Ситуация усугубляется также тем, что для большинства не видно возможностей самостоятельного преодоления существующего положения дел, поскольку нынешний социальный порядок не дает возможностей для развития вертикальной социальной мобильности. При этом, как показывают исследования Института социологии РАН, нельзя говорить о том, что нынешние поколения россиян хотели бы жить в обществе полного социального равенства; неравенства (даже достаточно глубокие) признаются легитимными, но лишь в том случае, если они проистекают из более высокого уровня образования, квалификации либо трудового вклада и, естественно, предполагают наличие честных возможностей для продвижения по социальной лестнице. «Таким образом, выбор общества равных возможностей - это устойчивая норма российской культуры, и, говоря о более справедливо устроенном обществе, две трети населения подразумевают именно равенство возможностей, а не доходов и уровня жизни» (Мареева, 2016: 157). Отличительной чертой российского социума в этом отношении является также то, что основные надежды по достижению социальной справедливости возлагаются на государство, однако граждане не верят в возможность осуществления справедливого общественно-экономического порядка. И в этом заключается парадокс (там же: 173).

Итак, согласно выводам социологов, справедливое общество в представлениях россиян - это общество равных возможностей, в котором существуют неравенства, но они рассматриваются как справедливые и необходимые с точки зрения развития экономики. С точки зрения же социальной структуры идеальное общество это общество не богатых и не бедных, но общество средних слоев, отличающихся устойчивым социально-экономическим статусом и достаточно высокими стандартами потребления. В целом можно говорить о том, что такие представления вполне соответствуют европейским и делают российскую культуру частью общеевропейской. В практическом же плане это означает необходимость более активной госу- 
дарственной политики, направленной как на социальную поддержку наименее обеспеченных, так и на выравнивание доходов и создание условий для роста численности среднего класса.

В настоящей статье мы ставим своими задачами, во-первых, изучение предпосылок и особенностей происхождения социального государства на Западе (с начала XIX в.); во-вторых, анализ основных существующих в современном мире моделей социальной защиты (которые соответствуют и основным историческим этапам становления социальной политики). Таким образом, анализ западного опыта становления и развития социального государства рассматривается нами как важная методологическая предпосылка решения данной проблемы в современной России.

\section{ИСТОРИЧЕСКИЕ ОСНОВЫ ФОРМИРОВАНИЯ СОЦИАИЬНОГО ГОСУААРСТВА}

Очень коротко социальное государство можно охарактеризовать как социальную инновацию Запада, возникшую в ответ на определенного рода проблемы, порожденные индустриальным капитализмом. Это прежде всего проблемы крайней бедности и неравенства. В рамках социального государства формируются определенные механизмы (прежде всего механизм социального страхования, а также социальной помощи), которые становятся способом недопущения крайней бедности и дальнейшей пролетаризации рабочего класса. C последней трети XIX в. на Западе были последовательно выработаны три основные модели социального государства - континентальная (модель Бисмарка), англосаксонская (модель Бевериджа) и скандинавская (или нордическая) модель. Однако прежде чем рассмотреть эти модели в их основных чертах, представляется важным рассмотреть основные предпосылки возникновения социального государства, которые формируются на рубеже XVIII-XIX столетий.

Итак, рубеж XVIII-XIX вв. - время промышленной революции на Западе, в результате которой последовательно формируется социально-экономический уклад, принципиально отличающийся от того, который характеризовал конец Средних веков и начало Нового времени. Прежде всего, это время становления современного капиталистического производства. Какие факторы способствовали формированию нового уклада? Как показывает в своем фундаментальном труде «История Западной Европы в Новое время» русский историк и социолог Н. И. Кареев (Кареев, 1894: 550-574), можно обозначить три таких фактора, которые, однако, находятся в тесной взаимосвязи друг с другом. Первый - обезземеливание крестьянства в Западной Европе, связанное с так называемой аграрной революцией, происходившей на протяжении XVIII - первой трети XIX столетия. Второй - разрушение традиционных для средневекового общества цеховых структур. И третий - введение машинного производства, которое в значительной мере сократило необходимость в ручном труде. Эти три фактора, по мнению Кареева, обусловили промышленный переворот указанного периода, который, в свою очередь, повлек кардинальные изменения в социальной структуре западного общества.

В целом развитие капиталистического промышленного производства, которое произошло под непосредственным влиянием трех обозначенных факторов, одновременно с невиданным ростом общественного благосостояния (что отмечается почти всеми исследователями) породило серьезнейшую социальную проблему, а именно пролетаризацию и обнищание рабочего класса - выходцев из бывших це- 
хов, мелких разорившихся ремесленников, но главным образом - бывших крестьян. Проблема пауперизма (от лат. pauper - бедный) - вот ключ к пониманию происхождения социального государства, которое с последней трети XIX в. (введение первой системы социального страхования в Германии) призвано было решать задачу кардинального улучшения положения рабочего класса.

В то же время возникает вопрос: чем, какими обстоятельствами было вызвано обнищание рабочих в конце XVIII - первой половине XIX в.? Это кажется тем более удивительным, что именно трудом рабочего класса создавалось благосостояние общества, и, казалось бы, непосредственные производители национального благосостояния должны были бы иметь достойный уровень жизни. Однако, как показывают исследователи проблемы пауперизма, капитализм указанного периода был устроен таким образом, что именно рабочие заводов и фабрик оказывались в социально наиболее невыгодном положении. Целый ряд факторов определял данное положение рабочих. Во-первых, это свободная конкуренция товаропроизводителей между собой, которая требовала, с одной стороны, постоянной заботы об улучшении качества продукции, а с другой - снижения издержек, что влекло снижение заработной платы рабочим. Второй фактор - это конкуренция между собой уже не товаропроизводителей, но непосредственных продавцов рабочей силы. В условиях капиталистической экономики предложение, как правило, превышает спрос на нее, поэтому образуется избыточное предложение, которое также позволяет капиталисту снижать цену на труд. Наконец, третий фактор - это периодические промышленные кризисы (спады производства), которые являются сущностной чертой капиталистической экономики. Как ярко показал в своей работе «Пролетарии и пауперизм в Англии и во Франции» известный русский экономист В. А. Милютин, промышленные кризисы в экономике, подобной английской, могут иметь поистине ужасающие социальные последствия (Милютин, 1946: 201-208).

Нельзя обойти вниманием такой фактор, как массовое внедрение машинной техники, который, кроме снижения спроса на квалифицированный труд, имел и другое крайне важное социальное последствие, а именно гомогенизацию рабочего класса, сосредоточение основных производительных сил на огромных фабриках и заводах, что, в свою очередь, означало уничтожение определенных социальных прослоек (мелких фабрикантов и ремесленников), которые ранее выступали в качестве своего рода посредствующих звеньев между классом крупных капиталистов и классом наемных рабочих-пролетариев. Это также означало и устранение ранее существовавших каналов социальной мобильности. Как с сожалением пишет русский экономист, «ныне в индустриальной армии мы не находим уже этой посредствующей ступени; ныне остались два сословия, отделенные друг от друга пропастию: с одной стороны несколько богачей, с другой множество пролетариев, которые находятся в полной зависимости от капиталистов и никогда не могут проникнуть в эту неприступную для них касту» (там же: 212).

Помимо описанных факторов ухудшения социально-экономического положения рабочих (главным образом через понижение заработной платы и формирование новой, менее справедливой социальной структуры), следует указать и на другие важные последствия, к которым приводило раннее капиталистическое производство и которые являются неразрывными сопутствующими явлениями при пауперизме. Во-первых, это разлагающее влияние, которое оказывал тяжелый, многочасовой труд на про- 
изводстве в условиях массового скопления на нравственное состояние людей, прежде всего женщин и детей. Во-вторых, истощение физических сил ( «физический упадок рабочих классов», как называет это Милютин). В-третьих, профессиональные болезни, которые нередко возникали в рамках тех или иных вредных производств (например, занятие точильщика или чесальщика шерсти). В-четвертых, отрицательное воздействие на умственное развитие рабочих (поскольку работа не оставляла времени для развития). Наконец, особую обеспокоенность неравнодушных людей (в том числе в структурах государственной власти) вызывало положение женщин и детей, которые наравне с мужчинами трудились на фабриках, но при этом были значительно ниже оплачиваемы и воздействие тяжелой, монотонной работы на организм которых было значительно вреднее, чем на мужской организм. Такое крайне неудовлетворительное положение в сфере женского и детского труда в конечном счете приводит к тому, что законодатели разных стран (первопроходцем здесь стала Англия) принимают соответствующие законы, направленные на регулирование труда этих категорий работников, которое предусматривало как сокращение продолжительности рабочего времени в зависимости от возраста работника, так и определенные ограничения (например, запрет работы в ночное время), а также требовало предоставления возможности в получении хотя бы начального образования. Это законодательство принималось сложно, на протяжении ряда лет (начиная с 1830-х годов), при активном сопротивлении работодателей, однако именно его (законодательство) в сфере регулирования женского и детского труда можно считать исходной точкой в сфере создания основ социального государства (см.: Чикалова, 2006).

И все же какие установления можно считать основополагающими для становления и развития европейского социального государства начиная со второй половины XIX в.? Ключевым моментом здесь становится постепенное введение системы государственного обязательного социального страхования. И, как известно, первопроходцем в этом отношении стала Германия, стараниями имперского канцлера О. фон Бисмарка введшая у себя (с начала 1880-х годов) три основополагающих закона (о страховании по болезни, от несчастных случаев, по старости и инвалидности). Однако это - лишь вершина айсберга, не менее важно понять и логику становления системы социального страхования. Как показывает в своих работах отечественный специалист в области истории и теории социального страхования Н. А. Вигдорчик, социальное страхование прошло в своей эволюции три основных этапа, которые он обозначает как: а) этап добровольного страхования; б) этап факультативно-обязательного и частного страхования; в) этап обязательного (или принудительного) страхования. Каждый из этих этапов, согласно точке зрения Вигдорчика, являлся необходимым в общей эволюционной логике становления социального страхования (Вигдорчик, 1923).

Н. А. Вигдорчик, ссылаясь на Э. Ренана, пишет, что первые союзы взаимопомощи и похоронные кассы в Риме и Греции устраивали уже первые христиане. Подобные же союзы со смешанным религиозно-экономическим содержанием существовали и в Средние века. Однако и в Античности, и в эпоху Средневековья деятельность этих организаций носила достаточно ограниченный характер, поскольку в целом социально-экономическое положение человека в обществе гарантировалось его принадлежностью к той или иной общине (сословие, цех, гильдия, церковный приход), которая и оказывала соответствующую материальную поддержку 
в трудных жизненных случаях. Однако ситуация меняется принципиальным образом с момента начала развития индустриального капитализма, когда впервые возникает такое явление, как промышленный пролетариат, лишенный (в отличие от традиционных социальных слоев) каких-либо прочных связей с определенной общиной. В этой ситуации естественным выходом из положения становится организация добровольных обществ взаимопомощи, которые и возникают впервые в середине XVIII в. в наиболее промышленно развитых странах - Англии и Франции. Еще одна форма коллективной взаимопомощи - рабочие союзы (тред-юнионы в Англии), которые предоставляли своим членам материальную помощь в трудных жизненных ситуациях (например, болезнь или смерть кормильца), однако для этих союзов такая деятельность не была специфичной - их работа была направлена в первую очередь на борьбу с предпринимателями. Аальнейшая эволюция института социального страхования, однако, требовала того, чтобы в конце концов перешагнуть этот рубеж и двинуться в сторону такой формы, как обязательное страхование. Почему это было необходимо? Во-первых, добровольное страхование имело достаточно узкий круг применения (поскольку регулярно платить страховые взносы могли только достаточно обеспеченные рабочие), а во-вторых, даже та помощь, которая предоставлялась, не отличалась интенсивностью. Преодолению указанных недостатков и должно было послужить введение обязательного страхования, которое: а) распространялось бы на всех рабочих без исключения (в том числе и самых бедных) и б) предоставляло бы значительно более щедрые социальные выплаты. Последнего же можно было достигнуть, лишь привлекая в фонды социального страхования дополнительные финансовые ресурсы - отчисления со стороны работодателей и непосредственные субсидии со стороны государства.

Однако, как показывает Вигдорчик, к идее обязательного социального страхования европейские страны пришли далеко не сразу - до этого были попытки всяческого поощрения добровольных обществ, затем - различные паллиативы в виде условно-обязательного и частного страхования. Первое предполагало обязательность, например, в форме установлений, идущих со стороны местных властей (и на их усмотрение), либо в результате особого коллективного договора между рабочими и предпринимателями. Второе получило развитие в некоторых отраслях промышленности, отличавшихся особыми тяготами капиталистической эксплуатации (прежде всего горнорабочие). Если же говорить действительно об обязательном всеобщем страховании, то первой его формой стало страхование от несчастных случаев на производстве, ответственность за которые полностью перекладывалась на работодателя. В этом смысле работодатель выступал в качестве страховщика, а пострадавшие рабочие оказывались в положении третьих лиц, получающих установленную страховку. Важным дополнением этого института стало страхование самих предпринимателей (в частных формах или взаимное) от наступления подобных страховых случаев.

Наконец, подлинным воплощением системы обязательного государственного социального страхования стали знаменитые законы, инициированные и принятые в последней трети XIX в. в Германии. Это, как мы уже сказали, законы 1883, 1884 и 1889 гг. - о страховании по болезни, от несчастных случаев и страховании на случай старости и инвалидности. Необходимыми условиями возникновения германского социального законодательства стали, с одной стороны, сильная централизо- 
ванная государственная власть, а с другой - наличие мощного рабочего движения, с требованиями которого нельзя было не считаться. В этих условиях и при моральной и интеллектуальной поддержке определенной части германского образованного класса (так называемый катедер-социализм, воплотившийся в принципы «Союза за социальную политику» (см.: Ефимов, 2015)) канцлер О. фон Бисмарк инициировал проведение реформ, направленных на значительное улучшение положения рабочего класса. Причем следует отметить, что первоначально реформы задумывались как обеспечивавшие высокий социально-экономический статус авангарда рабочего класса (влияния которого больше всего опасались немецкие консерваторы), однако затем, подчинившись требованиям остальной, более бедной, части пролетариата (торговые служащие, рабочие транспортных предприятий, ремесленники, сельскохозяйственные рабочие, домашняя прислуга), немецкие законодатели распространили систему социального страхования и на них. В то же время постепенно происходило и расширение функций социального страхования. «...Начав с страхования от болезней и несчастных случаев, Германия скоро перешла к страхованию от старости и инвалидности, а в 1911 г. ввела страхование вдов и сирот, т. е. страхование на случай смерти. <...> Постепенно прогрессирует и размер обеспечения, доставляемого застрахованным лицам страховыми учреждениями. <..> Помимо того, самый рост потребностей со стороны застрахованных лиц фактически раздвигает нормы помощи, оказываемые страховыми учреждениями. Улучшается постановка медицинской помощи, строятся собственные больницы, приюты для выздоравливающих, санатории и пр.» (Вигдорчик, 1923: 49-50). В конечном счете именно опыт Германии, передовой для того времени, стал образцом для проведения аналогичных реформ в других европейских странах, включая Россию.

Таким образом, повторим, именно система обязательного социального страхования, начиная с законов Бисмарка в Германии, стала основой, стержнем социального государства, по-разному воплотившись в разных странах западного мира. ОАнако именно она позволила преодолеть «язву» пауперизма, которая, по общему согласию исследователей индустриальной цивилизации, на протяжении более чем двух веков (XVIII, XIX и начало XX в.) сопровождала социально-экономическое развитие европейских государств (см.: Кастель, 2009; Хобсбаум, 1999; Розанваллон, 1997). Тем не менее, рассмотрев в общих чертах данный вопрос о происхождении социального государства, его истоках, представляется важным изучить коротко и основные модели социальной политики, которые естественно-исторически сложились в Западной Европе (см. об этом также: Социальная Европа в XXI веке, 2011: 173-347; Сидорина, 2005: 329-393).

\section{ОСНОВНЫЕ МОАЕАИ СОЦИААЬНОГО ГОСУААРСТВА}

Итак, исторически первая модель социального страхования, связанная с именем О. фон Бисмарка. В концептуальном плане особенность германской модели проясняет ее сравнение с другой знаменитой моделью - англосаксонской, связанной с именем британского государственного деятеля, лорда У. Бевериджа. Как показывает в своей известной статье «Классифицируя государства благосостояния: Авумерный подход» швейцарский исследователь А. Боноли (Bonoli, 1997; см. также: Сидорина, 2013: 68-71), модель Бисмарка (в сравнении с аналогичной моделью Бевериджа) характеризуется следующими чертами. Во-первых, бисмарковская соци- 
альная политика полностью основывается на социальном страховании; во-вторых, она обеспечивает не равномерные, а увязанные с предыдущим заработком страховые выплаты работникам; в-третьих, право на получение пособий обусловлено удовлетворительной историей страховых взносов; в-четвертых, финансирование страховых фондов основывается на взносах одновременно работников и работодателей. Главное же различие между моделью Бисмарка и моделью Бевериджа, согласно Боноли, заключается в тех целях, которые ставит себе социальная политика в обоих случаях: если социальная политика Бисмарка направлена на поддержание стабильного уровня дохода работников, то модель Бевериджа нацелена на предотвращение бедности (там же: 357). Исследователь пишет: «...в чисто Бисмарковском государстве благосостояния, строго говоря, не существует заботы в отношении бедности и в отношении той группы населения, которая не участвует в рынке труда. Бисмарковская социальная политика есть могущественный инструмент усиления позиций рабочих в рыночной экономике. <..> Напротив, Бевериджеанская социальная политика, определяемая как имеющая своей целью предотвращение бедности, очевидным образом направлена на все население страны, нежели является ограниченной определенной социальной группой, ибо в противном случае искоренение бедности было бы невозможно» (там же: 358 ).

Как здесь же поясняет Боноли, подобная позиция Бисмарка в отношении усиления положения рабочего класса имеет очень простое объяснение: немецкий канцлер хотел таким образом обеспечить лояльность рабочих (и прежде всего авангарда рабочего класса) германскому государству, тогда как другие группы населения, не представлявшие угрозы стабильности политического режима, Бисмарка попросту не интересовали (там же: 358$)$.

Наконец, еще одна черта бисмарковской модели, проистекающая из предыдущих. Ее особенность в том, что эта модель является в меньшей степени вертикально перераспределительной, чем это происходит в финансируемой из налоговых поступлений системе социальной помощи или универсальной системе социального обеспечения. В бисмарковском социальном страховании перераспределение осуществляется главным образом горизонтально, между людьми примерно одинакового уровня дохода, которые по-разному затронуты определенным социальным риском. Это происходит благодаря тому, что финансирование бисмарковского социального страхования основано на страховых взносах, и оно осуществляет выплаты, привязанные к предыдущему уровню доходов (там же: 363 ).

Модель Бисмарка иначе называют континентальной или корпоративистской моделью. От нее, как считают исследователи, принципиальным образом отличается модель Бевериджа, которую иначе именуют англосаксонской или универсалистской моделью. В чем ее основные особенности? Здесь весьма важно учитывать исторический контекст: если, как было сказано выше, модель Бисмарка возникает в исторических условиях, в которых консервативному германскому государству необходимо было справиться с социал-демократической «заразой» (и отсюда особая забота германского канцлера о рабочих - основной социальной базе социал-демократов), то модель Бевериджа возникает в условиях Второй мировой войны, когда социально-экономическое положение Великобритании было достаточно тяжелым. И в этих условиях военной и послевоенной разрухи важнейшей задачей Аля государственной политики становится не поддержание особого статуса той 
или иной социальной группы, но улучшение положения населения в целом. Не случайно поэтому, что главной целью, провозглашенной в знаменитом докладе Бевериджа (1942), было устранение бедности.

Как показывает итальянский исследователь А. Бенасси (Benassi, 2010; также: Сидорина, 2013: 55-68), фундаментальный принцип, который выдвигает (см. выше) Бевериджеанская система благосостояния, это принцип универсализма (в противоположность бисмарковской корпоративистской модели). «Все граждане, а не только определенные группы, выделенные в определенные времена, имеют право на гарантированный доход, чтобы устранить некоторые основные социальные риски (инвалидность, пожилой возраст, безработица, болезнь, материнство). Более того, эта система также является универсальной, потому что каждый призван делать равные страховые взносы, чтобы финансировать систему, и это делается не в соответствии с прогрессивной шкалой, определяемой индивидуальным или семейным экономическим положением. Иными словами, Беверидж очертил систему социальной защиты, где минимальный уровень благосостояния обеспечивается как право для всех граждан, независимо от любых особенных характеристик или правомочий, но в соответствии с которой каждый должен быть поддержан равно» (Benassi, 2010: 6).

Таким образом, наряду с универсализмом важнейшая идея модели Бевериджа заключается в том, что обеспечение более высокого, чем минимальный, уровня благосостояния, требует от человека индивидуальных усилий - государство же может гарантировать ему только тот набор социальных благ, который необходим для поддержания человеческого достоинства. В этом сказывается влияние либеральной политической культуры, традиционной для Великобритании, которая требует не лишать человека стимулов для самостоятельной активности. И в этом отношении (отказ от идеи поддержания высокого социально-экономического статуса отдельных социальных групп) модель Бевериджа также кардинальным образом отличается от бисмарковской модели.

Еще одно важное отличие заключается в том, что в системе Бевериджа страховые взносы и получаемые пособия не привязаны к определенному уровню заработной платы (как в бисмарковской модели): каждый, независимо от уровня своего дохода, делает равные взносы и, соответственно, в ситуации наступления страхового случая, получает равный размер пособий. При этом государство (а не самоуправляемые страховые кассы, как в Германии) через специальные фонды аккумулирует почти исключительным образом денежные страховые взносы, используемые для приобретения товаров или услуг, необходимых для поддержания ежедневного существования. В административном плане вместо множества различных учреждений, управляющих системой социальной поддержки (что тоже соответствовало добевериджской модели), вся система строго централизована и подчинена единому министерству социальной защиты с местными департаментами, которые несут прямую ответственность за администрирование всей системы социального страхования и социальной помощи.

Таким образом, Беверидж в своем докладе предложил достаточно простую схему, которая несколько усложняется, если принять во внимание им же предложенную категоризацию граждан в зависимости от их потребностей, а также различные формы социальной поддержки, кроме непосредственно социального страхования (см.: Farman, Perrins, 1947). 
Третья модель государства благосостояния, которую следует рассмотреть, это скандинавская или нордическая модель. Иногда в литературе говорят об англоскандинавской модели, объединяя в одну категорию социальную модель Бевериджа и модель, которая возникла в 1950-1960-е годы в таких странах, как Швеция, Норвегия и Аания. Отчасти такое сближение допустимо, поскольку скандинавская модель, как и модель Бевериджа, является универсалистской, однако есть и различия, которые весьма существенны. Самое главное различие заключается в том, что государства благосостояния, созданные в скандинавских странах, основывались отнюдь не на принципе минимального уровня благосостояния (как в англосаксонской модели), а на идее социального равенства, сопряженного с высоким уровнем жизни для всех граждан. Это различие связано с тем обстоятельством, что социальное государство Великобритании в целом создавалось в рамках либеральной политической культуры, для которой главное - свобода индивида при минимальном вмешательстве со стороны государства, тогда как социальные государства скандинавских стран создавались благодаря усилиям социал-демократических правительств, чья политика предполагала значительный уровень вмешательства государства в экономику и социальную сферу (включая сферу перераспределения).

В качестве наиболее яркого примера скандинавской модели рассмотрим шведскую модель.

Прежде всего, каковы предпосылки возникновения особой шведской модели государства благосостояния, которая считается уникальной. Как показывают некоторые авторы, обычно успех шведской модели связывают с длительным пребыванием у власти социал-демократов (с 1930-х годов с небольшими перерывами), однако более глубокие причины этого успеха обнаруживаются не только в соответствующей политике, но в значительной степени и в общественной и политической культуре шведов. Первая черта шведской национальной культуры, которая называется, это стремление к сотрудничеству, достижение целей путем переговоров, поиски и обретение консенсуса. Эта черта, как считается, обусловлена исторически и связана с характерным еще для средневековой Швеции широким народным представительством в органах власти (законодательных и судебных) (Плевако, 2015: Электронный ресурс). Весьма характерным примером такого духа сотрудничества является знаменитый Сальтшебаденский договор, заключенный в 1938 г. между Шведским объединением предпринимателей и Центральным объединением профсоюзов Швеции. С этих пор отношения между трудом и капиталом в Швеции регулировались практически без участия государства, а сами эти отношения на протяжении всего XX в. оставались исключительно мирными.

Вторая важная черта - демократизм шведского общества. Он проявлялся, в частности, в том, что «различия между сословиями выступали в Швеции не так очевидно, сословные ограничения и привилегии носили весьма условный характер...» (там же). Кроме того, демократизм шведского общества проявился в целом ряде народных движений, которые возникали начиная с середины XIX в. (движение за свободную церковь, движения за трезвость, кооперативное и рабочее движения). Важной особенностью здесь является то, что шведское государство не препятствовало развитию этих движений, а наоборот, способствовало их успеху. Во второй половине $\mathrm{XX}$ в. демократизм шведского общества со всей силой проявился и в успехе нового социального движения - за равные права женщин. 
Третья важнейшая черта - это стремление к справедливости и эгалитаризм шведов. Справедливость понимается прежде всего как равенство всех перед законом, что, в частности, означает чрезвычайно низкий уровень коррупции в Швеции. Эгалитаризм проявляет себя в очень небольшом разрыве в уровне доходов между верхними и нижними слоями населения. Важен также равный для всех доступ к качественному образованию и медицинскому обслуживанию.

Наконец, четвертая важная черта - толерантность шведов. С последней трети $\mathrm{XX}$ в. она проявляет себя в первую очередь по отношению к мигрантам. В целом шведская политика по отношению к мигрантам основывается на принципах мультикультурализма, когда приезжим предоставляются все социально-экономические и политические права, но сами они вольны самостоятельно определиться с тем, культуру какой страны они принимают в качестве своей - Швеции или страны исхода. Как и в других обществах, принявших мультикультурализм в качестве национальной политики, в Швеции действует целый ряд национальных программ, которые по замыслу их авторов должны способствовать развитию терпимости (там же).

Итак, социально-экономические и политические успехи шведского общества во многом связываются с культурой компромисса, которая характерна для разных слоев населения Швеции, а также с идеалами справедливости и равенства. Именно эти ценности, как считается, обусловили высокий уровень социальной солидарности в Швеции, на основе которого только и возможно было создать социал-демократическое государство благосостояния. Что же представляет собой само это государство благосостояния? Как определяется в одном из исследований, «суть шведской модели... сводится к следующему: государство всемерно и последовательно проводит "производственную" социальную политику, инвестируя средства в обеспечение занятости и мобильности рабочей силы, ее переподготовку, образование взрослых, профилактику болезней и несчастных случаев, помощь семьям» (Сафронов, 2008: Электронный ресурс). В основе такого типа социального государства, как уже отмечалось, лежит идеология социал-демократизма, которая сводится к следующим основным принципам: всеобщая занятость; единая социальная политика; производственная демократия; солидарная политика заработной платы; активная политика по формированию рынка труда; концепция образования коллективного капитала (там же).

Если говорить о шведской социальной политике, то она охватывает следующие сферы: взаимоотношения наемных работников и предпринимателей; выплаты пенсий и разного рода социальных пособий; забота о здоровье граждан; обеспечение нуждающихся муниципальным жильем; начальное, среднее и высшее образование; поиск гражданами нового места работы и их переквалификация.

Важнейшей чертой шведской социальной системы является перераспределение средств на социальные нужды из налоговых поступлений. При этом главный объект шведского налогообложения - не предприятие, а индивидуальный наемный труженик или (в меньшей степени) индивидуальный предприниматель. При этом для Швеции характерна двухуровневая система налогообложения: пропорциональная (доходы направляются в местные бюджеты) и прогрессивная (доходы идут центральному правительству). Отсюда такая известная черта шведской модели, как чрезвычайно высокий уровень налоговой нагрузки на население (до 80\% индивидуального дохода). 
В целом именно универсализм шведского государства благосостояния и высокая доля социальных трансфертов рассматриваются исследователями (в том числе критично настроенными) в качестве отличительной черты шведской модели. А. П. Сафронов полагает: «...корневое же противоречие шведской модели благосостояния, по нашему мнению, состоит в том, что она базируется не на контроле над индустриальным производством (т. е. на контроле над собственностью крупных и средних корпораций), а на контроле над распределением уже созданного продукта или, точнее, на контроле над частью заработной платы собственных граждан. Шведское “социальное государство” имеет единственным источником дохода налоги, и потому американский социолог и экономист Аж. Бьюкенен вполне законно называет подобный тип социально-политического устройства “государством трансфера"» (там же). Основное же обвинение в адрес шведского государства благосостояния заключается в том, что оно попросту забирает значительную часть дохода у своих граждан для того, чтобы вернуть им эти доходы в виде различного рода пособий и социальных выплат, но в значительно усеченном виде. В этом отношении социал-демократической модели Швеции противопоставляется либеральная новозеландская модель, в которой средства идут прежде всего на оказание помощи действительно нуждающимся и которая, таким образом, рассматривается как более эффективная (там же).

Аумается, однако, что, если даже у подобной критики есть весомые основания, они не умаляют основного достоинства шведской модели - сочетания высокого уровня социального равенства с высоким уровнем общественного благосостояния. Кроме того, как считают другие исследователи, основным элементом шведской модели является все же социальное страхование, а не просто перераспределение средств, полученных в рамках государственной налоговой системы (при том что государство как в лице центрального правительства, так и в лице муниципалитетов в значительной мере субсидирует социальные расходы) (Волков, 2016: 143).

В целом шведскую модель можно рассматривать как третью важнейшую ступень в развитии современного государства благосостояния, которая сумела сочетать универсализм, присущий англосаксонской модели (модели Бевериджа), с высоким уровнем жизни, на который была нацелена модель Бисмарка (но лишь в отношении определенной группы населения - промышленных рабочих). В свою очередь, предпосылками для проведения такой социальной политики стали как особенная общественная культура Швеции, так и определенные сдвиги в социальной структуре общества, выдвинувшие на авансцену не крестьянскую бедноту (как в первой половине XX в.), но представителей среднего класса с их высокими жизненными стандартами, что не могло не учитываться правящей социал-демократической партией Швеции (Эспинг-Андерсен, 2001).

\section{ЗАКАЮЧЕНИЕ}

Таким образом, мы рассмотрели историю формирования социального государства и основные модели социальной политики, которые сложились в странах ЗапаАа. Повторим, что данное рассмотрение, с нашей точки зрения, имеет важное методологическое значение, поскольку показывает, как, в каких условиях происходило формирование социального государства, и очерчивает те пути, которыми возможно формирование аналогичного института в России. Анализ трех основных моде- 
лей социальной политики (либеральной, консервативной и социал-демократической) также в определенной мере позволяет уяснить, на какие образцы мирового опыта может ориентироваться сегодняшняя Россия. Аумаем, что в большей мере российскому менталитету отвечает социал-демократическая модель, хотя и не все элементы успешного ее воплощения имеются в России (например, практика социального компромисса). Главное же, чему учит мировой опыт создания социального государства, - это поиск классового компромисса, который позволяет преодолеть разрыв, неизбежно образующийся между господствующими и подчиненными классами при капитализме.

\section{СПИСОК АИТЕРАТУРЫ}

Вигдорчик, Н. А. (1923) Теория и практика социального страхования. Вып. 1. Теоретические основы социального страхования. 2-е изд., испр. Пг. ; М. : Книгоиздательское товарищество «Книга». $151 \mathrm{c.}$

Волков, А. М. (2016) Шведская модель вчера и сегодня // Социальное государство в странах EC: прошлое и настоящее / отв. ред. Ю. А. Квашнин. М. : ИМЭМО РАН. 189 с. DOI: 10.20542/ 978-5-9535-0487-4. C. 137-154.

Ефимов, В. М. (2015) Социальный вопрос и социальное государство в Европе второй половины XIX века // Народонаселение. № 2. Апрель - июнь. С. 9-27.

Канарш, Г. Ю. (2014) Прошлое и будущее национальной идеи в России // Вестник Российской академии наук. Т. 84. № 5. С. 441-447.

Кареев, Н. И. (1894) История Западной Европы в Новое время (Развитие культурных и социальных отношений). T. IV. XIX век - Консульство, Империя и Реставрация. СПб. : Типография М. М. Стасюлевича. 645 с.

Кастель, Р. (2009) Метаморфозы социального вопроса. Хроника наемного труда : пер. с фр. ; общ. ред. пер. Н. А. Шматко. СПб. : Алетейя. 574 с.

Мареева, С. В. (2016) Справедливость и равенство в мечтах россиян и реалии современной России // «Идеальное общество» в мечтах людей в России и Китае / М. К. Горшков и др. ; отв. ред. М. К. Горшков, П. М. Козырева, Аи Пэйлинь, Н. Е. Тихонова. М. : Новый хронограф. 424 с. C. $152-174$.

Милютин, В. А. (1946) Пролетарии и пауперизм в Англии и во Франции. Статья первая // Милютин, В. А. Избранные произведения. М. : ОГИЗ, Государственное издательство политической литературы. 445 с. С. 158-237.

Плевако, Н. С. (2015) Шведская модель: прошлое и настоящее [Электронный ресурс]// Аналитическая записка. №11 / Институт Европы PAH. URL: http://instituteofeurope.ru/images/ uploads/analitika/an11.pdf (дата обращения: 12.12.2017).

Розанваллон, П. (1997) Новый социальный вопрос. Переосмысливая государство всеобщего благосостояния : пер. с фр. М. : Ad Marginem. 188 с.

Сафронов, А. П. (2008) Внутренние противоречия шведской модели «благосостояния» [Электронный ресурс]// Научный эксперт. Научный электронный журнал. Вып. 11. C. 72-79. URL: http://riskprom.ru/_ld/0/80_NEx_11_2008_Swe.pdf (дата обращения: 12.12.2017).

Сидорина, Т. Ю. (2013) Государство всеобщего благосостояния: от утопии к кризису. М. : РГГУ. 349 с.

Сидорина, Т. Ю. (2005) Ава века социальной политики. М. : РГГУ. 442 с.

Социальная Европа в XXI веке (2011) / под ред. М. В. Каргаловой. М. : Изд-во «Весь мир». $528 \mathrm{c}$.

Тихонова, Н. Е. (2016) Материальная сторона жизни в мечтах россиян и в реальности // «Идеальное общество» в мечтах людей в России и Китае : монография / М. К. Горшков и др. ; отв. ред. М. К. Горшков, П. М. Козырева, Аи Пэйлинь, Н. Е. Тихонова. М. : Новый хронограф. 424 c. C. $20-45$. 
Хобсбаум, Э. (1999) Век революции. Европа 1789-1848 / пер. с англ. А. А. Якуниной. Ростов н/А. : ИзА-во «Феникс». 480 с.

Чикалова, И. Р. (2006) У истоков социальной политики государств Западной Европы // Журнал исследований социальной политики. Т. 4. № 4. С. 501-524.

Эспинг-Андерсен, Ё. (2001) Создание социал-демократического государства благосостояния // Создавая социальную демократию. Сто лет социал-демократической рабочей партии Швеции : пер. с англ.; предисл. Ю. М. Аужкова. М. : Весь мир. 591 с. С. 85-93.

Benassi, D. (2010) "Father of the Welfare State"? Beveridge and the Emergence of the Welfare State // Sociologica. № 3. P. 1-21. DOI: 10.2383/33647

Bonoli, G. (1997) Classifying Warfare States: a Two-dimension Approach // Journal of Social Policy. Vol. 26. Issue 3. July. P. 351-372.

Farman, C., Perrins, C. (1947) The New British System of Social Security // Social Security Bulletin. February. P. 9-19.

Lата поступления: 20.12.2017 г.

\section{SOCIAL STATE: HISTORICAL GENESIS AND CONTEMPORARY MODELS \\ G. Y. KANARSH \\ InStITUTE OF PHILOSOPHY, RUSSIAN ACADEMY OF SCIENCES}

The article raises the issue of the social state, which is a key issue for the modern Russian society. The author refers to the results of sociological surveys which indicate that the Russian society does not quite satisfy the criteria of a prosperous society. On the one hand, the well-being of the Russian society has been steadily increasing throughout the 2000s and 2010s; on the other hand, social inequality has been growing simultaneously. As a result, the Russian society is characterised by an extremely high level of social stratification, despite the fact that the prosperity level has grown over the last 17 years. This circumstance, as well as a very low level of social welfare of Russian citizens, according to the author, makes it necessary to bring up the issue of the social state.

The author proposes to use the comparative historical approach to analysing the formation of a social state. From his point of view, understanding the ways in which a social state can be formed in Russia involves the analysis of the ways of its formation in the West (Western Europe and USA). The article analyses the origins of the social state (the issue of pauperism), historical solutions to the social issue (different model of social insurance), and examines basic models of social policy (conservative, liberal, and social democratic).

The main thesis is that a social state is an institution that embodies the practice of class compromise, the willingness of the ruling classes to renounce part of their interests for the sake of social stability. The conclusion is that Russia is closer to the social democratic model of social policy; however, not all conditions for its implementation are available.

Keywords: social state; social policy; pauperism; social insurance; conservatism; liberalism; social democracy; Bismarck; Beveridge; Swedish model

\section{REFERENCES}

Vigdorchik, N. A. (1923) Teoriia i praktika sotsial'nogo strakhovaniia. Iss. 1. Teoreticheskie osnovy sotsial'nogo strakbovaniia. 2nd ed., revised and enlarged. Petrograd, Moscow, Kniga. 151 p. (In Russ.)

Volkov, A. M. (2016) Shvedskaia model' vchera i segodnia. In: Sotsial'noe gosudarstvo v stranakb ES: prosbloe i nastoiasbchee / ed by Yu. D. Kvashnin. Moscow, IMEMO RAN. 189 p. DOI: 10.20542/978-5-9535-0487-4. Pp. 137-154. (In Russ.)

Efimov, V. M. (2015) Sotsial'nyi vopros i sotsial'noe gosudarstva v Evrope vtoroi poloviny XIX veka. Narodonaselenie, no. 2, April-June, pp. 9-27. (In Russ.)

Kanarsh, G. Iu. (2014) Proshloe i budushchee natsional'noi idei v Rossii. Vestnik Rossiiskoi akademii nauk, vol. 84, no. 5, pp. 441-447. DOI: 10.7868/S0869587314050089 (In Russ.) 
Kareev, N. I. (1894) Istoriia Zapadnoi Evropy v Novoe vremia (Razvitie kul'turnykb i sotsial'nykb otnoshenii). Vol. IV. XIX vek - Konsul'stvo, Imperiia i Restavratsiia. Saint-Petersburg, Tipografiia M. M. Stasiulevicha. 645 p. (In Russ.)

Kastel', R. (2009) Metamorfozy sotsial' nogo voprosa. Kbronika naemnogo truda: translated from French ; ed. by N. A. Shmatko. St. Petersburg, Aleteiia. 574 p. (In Russ.)

Mareeva, S. V. (2016) Spravedlivost' $i$ ravenstvo $v$ mechtakb rossiian i realii sovremennoi Rossii. In: «Ideal'noe obshchestvo» v mechtakb liudei v Rossii i Kitae: [monografiia] / [M. K. Gorshkov i dr.] ; M. K. Gorshkov, P. M. Kozyreva, Li Peilin' and N. E. Tikhonova (eds.). Moscow, Novyi khronograf. 424 p. Pp. 152-174. (In Russ.)

Miliutin, V. A. (1946) Proletarii i pauperizm v Anglii i vo Frantsii. Stat'ia pervaia. In: Miliutin V. A. Izbrannye proizvedeniia. Moscow, OGIZ, Gosudarstvennoe izdatel'stvo politicheskoi literatury. $445 \mathrm{p}$. Pp. 158-237. (In Russ.)

Plevako, N. S. (2015) Shvedskaia model': proshloe i nastoiashchee. In: Analiticheskaia zapiska, no. 11 [online] Available at: http://instituteofeurope.ru/images/uploads/analitika/an11.pdf (access date: 29.01.2018). (In Russ.) (In Russ.)

Rozanvallon, P. (1997) Novyi sotsial' nyi vopros. Pereosmyslivaia gosudarstvo vseobshch. blagosostoianiia: [translated from French]/ P'er Rozanvallon, Moscow, Ad Marginem. 188 p. (In Russ.)

Safronov, A. P. (2008) Vnutrennie protivorechiia shvedskoi modeli "blagosostoianiia". In: Naucbnyi ekspert. Nauchnyi elektronnyi zburnal, iss. 11, pp. 72-79 [online] Available at: http:// riskprom.ru/_ld/0/80_NEx_11_2008_Swe.pdf (access date: 29.01.2018) (In Russ.) (In Russ.)

Sidorina, T. Yu. (2013) Gosudarstvo vseobshchego blagosostoianiia: ot utopii k krizisu. Moscow, RGGU. 349 p. (In Russ.)

Sidorina, T. Yu. (2005) Dva veka sotsial' noi politiki. Moscow, RGGU. 442 p. (In Russ.)

Sotsial' naia Evropa v XXI veke (2011)/ ed. by M. V. Kargalovoi Moscow, Ves' Mir. 528 p. (In Russ.)

Tikhonova, N. E. (2016) Material'naia storona zhizni v mechtakh rossiian i v real'nosti. In: "Ideal' noe obshchestvo»v mechtakb liudei v Rossii i Kitae: [monografiia]/ [M. K. Gorshkov et al.]; M. K. Gorshkov, P. M. Kozyreva, Li Peilin' and N. E. Tikhonova (eds.). Moscow, Novyi khronograf. 424 p. Pp. 20-45. (In Russ.)

Khobsbaum, E. (1999) Vek revoliutsii. Evropa 1789-1848 / translated from English by L. D. Iakuninoi. Rostov on Don, izd-vo "Feniks". 480 p. (In Russ.)

Chikalova, I. R. (2006) U istokov sotsial'noi politiki gosudarstv Zapadnoi Evropy. Zhurnal issledovanii sotsial'noi politiki, vol. 4, no. 4, pp. 501-524. (In Russ.)

Esping-Andersen, E. (2001) Sozdanie sotsial-demokraticheskogo gosudarstva blagosostoianiia. In: Sozdavaia sotsial'nuiu demokratiiu. Sto let sotsial-demokraticheskoi rabochei partii Shvetsii / translated from English; preface by Yu. M. Luzhkov. Moscow, Ves' mir. 591 p. Pp. 85-93. (In Russ.)

Benassi, D. (2010) "Father of the Welfare State"? Beveridge and the Emergence of the Welfare State. Sociologica, no. 3, pp. 1-21. DOI: 10.2383/33647

Bonoli, G. (1997) Classifying Warfare States: a Two-dimension Approach. Journal of Social Policy, vol. 26, issue 3, July, pp. 351-372. (In Russ.)

Farman, C., Perrins, C. (1947) The New British System of Social Security. Bulletin, February, pp. 9-19. (In Russ.)

Submission date: 20.12 .2017$.

Канарш Григорий Юрьевич - кандидат политических наук, старший научный сотрудник сектора социальной философии Института философии РАН. Адрес: 109240, Россия, г. Москва, ул. Гончарная, А. 12, стр. 1. Тел.: +7 (495) 697-98-93. Эл. aдpec: grigkanarsh@yandex.ru

Kanarsh Grigory Yuryevich, Candidate of Politology, Senior Research Fellow, Sector of Social Philosophy, Institute of Philosophy, Russian Academy of Sciences. Postal address: 12, Bldg. 1, Goncharnaya St., Moscow, Russian Federation, 109240. Tel.: +7 (495) 697-98-93. E-mail: grigkanarsh@yandex.ru 